\title{
ПСИХОПАТОЛОГІЧНА ФЕНОМЕНОЛОГІЯ ДЕПРЕСИВНИХ РОЗЛАДІВ 3 УРАХУВАННЯМ ФАКТОРА МІГРАЦІї
}

\author{
๑О. П. Венгер, О. Є. Смашна, Ю. І. Мисула, В. С. Білоус, Л. М. Сас, \\ О. О. Люта, Я. М. Несторович, Т. П. Гусєва
}

ДВНЗ «Тернопільський державний медичний університет імені І. Я. Горбачевського мОЗ України»

РЕЗЮМЕ. Сучасна політична та економічна ситуація в Україні обумовлює те, що явища еміграції та рееміграції входять до числа найактуальніших державних та суспільних проблемних питань. Згідно з даними Міжнародної організації з міграції, станом на 2011 рік кількість українських емігрантів складала близько 6,5 млн осіб (14,4% постійного населення).

Мета дослідження - вивчення синдромологічних особливостей депресивних розладів у емігрантів та реемігрантів.

Матеріал і методи. Клінічно обстежено 98 емігрантів, 95 реемігрантів та 98 не емігрантів, хворих на депресивні розлади психогенного, ендогенного та органічного характеру.

Результати. Виявлена більша ураженість реемігрантів типовими афективними синдромами - вітальної та апатичної депресії, а емігрантів - атиповими афективними синдромами, зокрема, тривожно-депресивними та ажитації, що можна пояснити впливом об'єктивних соціально-психологічних факторів, а також інтрапсихічною трансформацією актуальних стресогенних подразників, пов'язаних з еміграцією та рееміграцією.

Висновки. 1. Фактор еміграції та рееміграції впливає на психоемоційну сферу емігрантів та реемігрантів, хворих на депресивні розлади різного ґенезу, про що свідчать особливості виявленої нами в процесі дослідження психопатологічної симптоматики. 2. Пацієнти з психогенними депресивними розладами найбільше піддаються впливу фактора еміграції, порівняно з пацієнтами із ендогенними та органічними депресіями. 3. Контингент емігрантів та реемігрантів відрізняється значуще більш вираженими ознаками соматизації, обсесивно-компульсивних розладів і тривожності, дещо вищими компонентами ворожості та фобічної тривожності. 4. Найбільш вираженими показниками, що характеризують депресивні та астенічні тенденції у реемігрантів, були ознаки депресії та міжособистісної сенситивності, а також індекс виразності дистресу. На наш погляд, причинами цих відмінностей $\epsilon$ вплив об'єктивного фактора фрустрації у групі реемігрантів та тривожних побоювань щодо можливості продовження роботи за кордоном у зв'язку із психічним захворюванням - у емігрантів.

КЛючОВІ СлОВА: міграція; депресивний розлад; психогенні депресивні розлади; ендогенні депресивні розлади; органічні депресивні розлади.

Вступ. Сучасна політична та економічна ситуація в Україні обумовлює те, що явища еміграції та рееміграції входять до числа найбільш актуальних державних та суспільних проблемних питань. Згідно даних Міжнародної організації з міграції, станом на 2011 рік кількість українських емігрантів складала близько 6,5 млн осіб (14,4 \% постійного населення) [1]. Офіційна еміграція при цьому складає незначну частину загального обсягу еміграції; натомість переважна більшість мігрантів (від 60 до 90 \%) виїжджають за кордон з задекларованою метою туризму, відвідування родичів тощо з подальшим працевлаштуванням (легальним або нелегальним) у країнах-реципієнтах [1]. Явище еміграції розглядається як фактор, що провокує маніфестацію або екзацербацію ендогенних психічних захворювань [3-5].

Наукові дані щодо структури і поширеності психічних розладів серед емігрантів $\epsilon$ недостатніми і вкрай суперечливими. В структурі психічних розладів емігрантів домінують психодезадаптаційні стани, посттравматичний стресовий розлад, неврастенія, пролонгована депресивна реакція та помірний депресивний епізод [6-9], а психологічні особистості емігрантів характеризуються слабкою інтеграцією особистісних рис у вигляді емотивності та фрустрованості, низькимй рівнем фрустраційної толерантності, емоційною нестійкістю, тривожністю, соціальною інтроверсією, конформністю на поведінковому рівні, підозріливістю.

В Україні, незважаючи на виняткову актуальність проблеми еміграції, взагалі відсутні серйозні наукові дослідження, що спрямовані на вивчення депресивних розладів у емігрантів та реемігрантів.

Мета дослідження - виявити особливості та закономірності психопатологічної симптоматики у емігрантів та реемігрантів, що страждають на депресивні розлади.

Матеріал і методи дослідження. Було обстежено 98 осіб, які щонайменше протягом останнього року проживали за межами України і планували найближчим часом повернутися за кордон (емігранти), 95 осіб, які не менше року проживали за межами України і протягом останнього року повернулися для постійного проживання в Україну (реемігранти) та 99 осіб, які постійно проживають в Україні і ніколи не виїжджали за ії межі для 
Огляди літератури, оригінальні дослідження, погляд на проблему, ювілеї

тривалого проживання (не емігранти). Відповідно до критеріїв MKX-10 усім обстеженим був встановлений остаточний клінічний діагноз депресивного розладу, з них психогенні депресивні розлади (коди за MKX-10 F43.21 та F43.22) були у 35 не емігрантів, 34 емігрантів та 33 реемігрантів, ендогенні (коди за MKX-10 F31.3, F31.4, F32.1, F32.2, F33.1 та F33.2) - відповідно у 32, 33 та 32 осіб, органічні (код за MKX-10 F06.3) - відповідно у 32, 31 та 30 осіб; розбіжності між групами не значущі. Було використано опитувальник вираженості психопатологічної симптоматики Symptom Check List-90-Revised - SCL-90-R [10]. Статистичний аналіз результатів проводився за допомогою непараметричного тесту Манна-Уїтні.

Результати й обговорення. При дослідженні синдромологічних особливостей у емігрантів та реемігрантів виявлені певні особливості, пов'язані з впливом фактора еміграції (рееміграції).

Пацієнти, що страждали на психогенні депресивні розлади, характеризувалися значимими відмінностями у вираженості психопатологічної симптоматики з урахуванням фактора еміграції (рееміграції). Показник за шкалою соматизації, який відображає дистрес унаслідок неприємних соматичних відчуттів (соматовегетативний компонент), $\epsilon$ найвищим у емігрантів - $(0,87 \pm 0,53)$ балів проти $(0,66 \pm 0,40)$ балів у реемігрантів та $(0,51 \pm 0,34)$ балів у не емігрантів. Розбіжності значущі при порівнянні груп не емігрантів та емігрантів $(p<0,01)$, не емігрантів та реемігрантів $(p<0,05)$, емігрантів та реемігрантів $(p<0,05)$. Аналогічні закономірності виявлені при дослідженні виразності обсесивно-компульсивних розладів: найвищий показник за цією шкалою був у емігрантів $((1,43 \pm 0,77)$ балів), дещо менший - у реемігрантів $((1,13 \pm 0,44)$ балів), і найменший - у не емігрантів $((0,98 \pm 0,48)$ балів). Розбіжності значущі при порівнянні груп не емігрантів та емігрантів $(p<0,01)$, не емігрантів та реемігрантів $(p<0,1)$, емігрантів та реемігрантів $(p<0,05)$. Найбільшою мірою група емігрантів відрізняється за показниками тривожності - $(1,73 \pm 1,07)$ балів проти $(1,32 \pm 0,84)$ балів у реемігрантів та $(1,07 \pm 0,98)$ балів у не емігрантів. Значущі розбіжності виявлені для груп не емігрантів та емігрантів $(p<0,01)$, не емігрантів та реемігрантів $(p<0,05)$ і емігрантів та реемігрантів $(p<0,05)$. Також у емігрантів були виявлені дещо вищі показники за шкалами ворожості (що включає думки, почуття або дії, що $є$ проявами негативного афективного стану злості - агресію, дратівливість, гнів та обурення): $(0,72 \pm 0,92)$ балів порівняно з реемігрантами $((0,60 \pm 0,85)$ балів) та не емігрантами $((0,57 \pm 0,90)$ балів), однак, значущі розбіжності $(p<0,01)$ виявлені лише при порівнянні емігрантів та не емігрантів. Аналогічні законо- мірності виявлені при аналізі показників фобічної тривожності (стійка реакція страху на певних людей, місця, об'єкти або ситуації, що характеризується як ірраціональна і супроводжується поведінкою уникання): у не емігрантів вони $\epsilon$ найнижчими $(0,61 \pm 0,39$ балів), у реемігрантів - помітно вищими $(0,68 \pm 0,29$ балів), а у емігрантів - найвищими $(0,74 \pm 0,54)$. Натомість, у реемігрантів найбільш вираженими були показники, що характеризують депресивні та астенічні тенденції. Так, показник депресії у цій групі склав $(2,98 \pm 0,35) 6 а-$ лів (у емігрантів $(2,61 \pm 0,59)$ балів, у не емігрантів $(2,40 \pm 0,45)$ балів), розбіжності значущі при порівнянні груп не емігрантів та емігрантів $(p<0,05)$, не емігрантів та реемігрантів $(p<0,01)$, і емігрантів та реемігрантів $(p<0,01)$. Показник міжособистісної сенситивності (відчуття власної неадекватності або неповноцінності, особливо у порівнянні себе з іншими) у реемігрантів склав $(1,24 \pm 0,33)$ балів, що значуще $(p<0,05)$ більше, ніж у емігрантів $((1,15 \pm$ $0,35)$ балів) та не емігрантів $((0,95 \pm 0,29)$ балів). Очевидно, що підвищення показників за цими шкалами $є$ відображенням найбільшої виразності фрустраційних тенденцій серед реемігрантів та переживанням власної неповноцінності та неспроможності як під впливом депресивних переживань, так і внаслідок усвідомлення об'єктивних проблем і труднощів.

Індекс проявлення симптоматики (кількість пунктів, на які дана позитивна відповідь - від 1 до 4 балів) також $\epsilon$ найвищим у емігрантів $(44,87 \pm 11,40)$ балів проти $(43,64 \pm 8,72)$ балів у реемігрантів та $(38,77 \pm 10,33)$ балів у не емігрантів. Значущі розбіжності виявлені при порівнянні груп не емігрантів та емігрантів $(p<0,01)$, не емігрантів та реемігрантів $(p<0,01)$. Натомість, індекс виразності дистресу $\epsilon$ найвищим у реемігрантів $((2,45 \pm 0,23)$ балів), дещо меншим - у емігрантів $((2,40 \pm 0,42)$ балів), і найменшим - у не емігрантів $((2,25 \pm 0,29)$ балів). Розбіжності значущі при порівнянні груп не емігрантів та емігрантів $(p<0,05)$ та не емігрантів і реемігрантів $(p<0,01)$.

Таким чином, для реемігрантів типовою $\epsilon$ більша виразність депресивних та астено-невротичних проявів, тоді як для емігрантів - тривожних, фобічних та соматизованих розладів.

Для хворих на ендогенні депресивні розлади характерні більш глибокі зміни у афективній сфері і пов'язаних з нею сферах. При цьому особливості психопатологічної симптоматики у них мають як спільні риси з хворими на психогенні депресії, так і певні відмінності. Зокрема, виразність проявів соматизації $\epsilon$ найбільшою у емігрантів (середній показник $(1,17 \pm 0,83)$ балів), меншою-у реемігрантів $((0,83 \pm 0,48)$ балів), і найменшою - y не емігрантів $((0,77 \pm 0,70)$ балів). Значущі розбіж- 
Огляди літератури, оригінальні дослідження, погляд на проблему, ювілеї

ності виявлені при порівнянні груп не емігрантів та емігрантів $(p<0,01)$, не емігрантів та реемігрантів $(p<0,05)$, емігрантів та реемігрантів $(p<0,05)$. Аналогічні закономірності виявлені для розладів тривожного спектра: тривожності (показники відповідно $(1,90 \pm 1,10)$ балів, $(1,47 \pm 0,97)$ балів та $(1,14 \pm 1,01)$ балів, розбіжності значущі для груп не емігрантів та емігрантів $(p<0,01)$, не емігрантів та реемігрантів $(p<0,05)$, емігрантів та реемігрантів $(p<0,05)$, обсесивно-компульсивних розладів (відповідно $(1,54 \pm 0,66)$ балів, $(1,34 \pm 0,52)$ балів та $(1,07 \pm 0,44)$ балів, розбіжності значущі для груп не емігрантів та емігрантів $(p<0,01)$, не емігрантів та реемігрантів $(p<0,01)$, емігрантів та реемігрантів $(p<0,1)$, та фобічної тривожності (відповідно $(0,76 \pm 0,44)$ балів, $(0,68 \pm 0,23)$ балів та $(0,67 \pm 0,40)$ балів, розбіжності значущі при порівнянні не емігрантів та емігрантів $(p<0,1)$, не емігрантів та реемігрантів $(p<0,05)$. Показник ворожості $\epsilon$ незначно більшим у не емігрантів, ніж у емігрантів (відповідно $(0,66 \pm 0,82)$ балів, $(0,59 \pm 0,87)$ балів та $(0,58 \pm$ $0,90)$ балів, однак розбіжності між групами, на відміну від психогенної депресії, $\epsilon$ незначущими. Також незначущими $\epsilon$ розбіжності за показниками психотизму та паранойяльних симптомів. Щодо проявів депресії, то вони $\epsilon$ найбільш вираженими у реемігрантів $((3,18 \pm 0,26)$ балів), дещо меншими у емігрантів $((2,79 \pm 0,42)$ балів) і найменшими -у не емігрантів $((2,63 \pm 0,30)$ балів). Розбіжності значущі при порівнянні між собою усіх груп $(p<0,01)$. Показник міжособистісної сенситивності також $\epsilon$ найвищим у реемігрантів $((1,36 \pm 0,45)$ балів), однак, друге місце займають не емігранти $((1,10 \pm 0,32)$ бали), і найнижчий показник виявлений у емігрантів $((1,07 \pm 0,49)$ балів). Значущі розбіжності виявлені при порівнянні груп не емігрантів і реемігрантів $(p<0,01)$ та емігрантів та реемігрантів $(p<0,01)$. Таким чином, прояви міжособистісної сенситивності (у хворих на депресивні розлади вона проявляється насамперед відчуттям власної неповноцінності та неспроможності) у емігрантів $\epsilon$ найменш вираженими, що, на наш погляд, $є$ відображенням специфічного соціального-психологічного статусу емігрантів, які мають більші можливості для заробітку і позбавлені ряду актуальних проблем, притаманних сучасному українському суспільству. Реемігрантам, які з тих чи інших причин не змогли реалізувати себе під час роботи за кордоном і змушені повернутися на батьківщину, притаманна найгірша самооцінка і найвищі рівні міжособистісної сенситивності, що також, на наш погляд, $є$ адекватним наслідком психологічної переробки ситуації депривації, необхідності адаптуватися до складних реалій та фрустраційних проявів.

Інтегральний показник серед хворих на ендогенні депресивні розлади $\epsilon$ найбільшим у емі- грантів $((1,38 \pm 0,47)$ балів), незначно меншим - у реемігрантів $((1,34 \pm 0,35)$ балів), і суттєво нижчим - у не емігрантів $((0,77 \pm 0,70)$ балів). Значущі розбіжності виявлені при порівнянні груп не емігрантів та емігрантів $(p<0,01)$, не емігрантів та реемігрантів $(p<0,01)$.

Аналогічно, найвищий індекс проявлення симптоматики виявлений у емігрантів - $(47,82 \pm$ $11,08)$ балів, менший-у реемігрантів $((46,05 \pm 9,88) 6 а$ лів), і найменший-уне емігрантів $((44,51 \pm 12,75)$ балів). Розбіжності виявлені лише при порівнянні груп не емігрантів та емігрантів $(p<0,01)$.

Індекс виразності дистресу $\epsilon$ найвищим у реемігрантів $((2,60 \pm 0,16)$ балів), дещо меншим - у емігрантів $((2,53 \pm 0,34)$ балів), і найнижчим - у не емігрантів $((2,30 \pm 0,28)$ балів). Розбіжності значущі при порівнянні груп не емігрантів та емігрантів $(p<0,01)$ та не емігрантів і реемігрантів $(p<0,01)$.

Депресивні розлади органічного ґенезу $\epsilon$ більш ригідними у плані психопатологічної симптоматики. Однак, фактор еміграції (рееміграції) чинить певний вплив на особливості психопатологічних проявів і у цій групі хворих. Так, значущі розбіжності у показниках між усіма групами (емігрантів, реемігрантів та не емігрантів) були виявлені за соматизацією (відповідно $(1,33 \pm 0,68)$ балів, $(0,93 \pm 0,32)$ балів та $(0,91 \pm 0,64)$ балів), тривожністю (відповідно $(1,99 \pm 0,67)$ балів, $(1,68 \pm 0,60)$ балів та $(1,43 \pm 1,03)$ балів), фобічною тривожністю $((0,91 \pm$ $0,45)$ балів, $(0,75 \pm 0,31)$ балів та $(0,66 \pm 0,39)$ балів). За всіма цими шкалами найвищі показники виявляються у емігрантів, найнижчі - у не емігрантів, а показники реемігрантів займають проміжне положення. Натомість показники депресії та міжособистісної сенситивності $\epsilon$ найвищими у реемігрантів (відповідно $(3,16 \pm 0,48)$ балів та $(1,43 \pm$ $0,40)$ балів), меншими - у емігрантів (відповідно $(2,92 \pm 0,41)$ балів та $(1,21 \pm 0,34)$ балів), і найменшими -у не емігрантів (відповідно $(2,66 \pm 0,51)$ балів та $(1,11 \pm 0,38)$ балів). Значущі розбіжності між групами не емігрантів та емігрантів, емігрантів та реемігрантів виявлені за показниками обсесивно-компульсивних розладів (відповідно $(1,10 \pm 0,63)$ балів, $(1,49 \pm 0,51)$ балів та $(1,25 \pm 0,61)$ балів). За рештою показників значущих розбіжностей не виявлено.

Інтегральний показник значуще $(p<0,01)$ відрізняється у групах не емігрантів $((1,22 \pm 0,40)$ балів) та емігрантів $((1,47 \pm 0,36)$ балів), а також не емігрантів та реемігрантів $((1,40 \pm 0,30)$ балів), як і індекс проявлення симптоматики $((44,72 \pm 10,91)$ балів, $(51,31 \pm 7,97)$ балів та $(50,23 \pm 5,98)$ балів відповідно).

Індекс виразності дистресу $\epsilon$ значуще вищим у емігрантів $((2,55 \pm 0,27)$ балів), порівняно 3 не

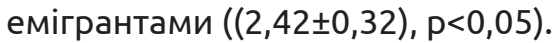

В цілому одержані дані свідчать про більшу виразність типових афективних синдромів, зо- 
Огляди літератури, оригінальні дослідження, погляд на проблему, ювілеї

крема, вітальної та апатичної депресії, у реемігрантів, а атипових, насамперед, тривожно-депресивних - у емігрантів. Це може бути пояснено дією об'єктивної соціально-психологічної ситуації: у групі реемігрантів найбільш виражені прояви фрустрації, що пов'язано з необхідністю адаптації до сучасного українського суспільства із гіршими соціально-економічними та суспільно-політичними умовами, порівняно з європейськими. Це закономірно призводить до більшої виразності апатичних та ізольованих депресивних проявів суму, зниженого настрою, ангедонії. Натомість, у емігрантів мобілізуючим фактором є усвідомлення необхідності повернення за кордон, що водночас асоціюється із тривогою і побоюваннями щодо можливості продовження трудової діяльності у зв'язку з психічним захворюванням. Вплив фактора еміграції (рееміграції) на відмінності у синдромологічній структурі депресивних розладів у хворих з психогенними депресивними розладами є найбільшим, а з органічними - найменшим серед усіх досліджених груп, що є закономірним з урахуванням характеру патології.

Висновки. 1. Фактор еміграції та рееміграції впливає на психоемоційну сферу емігрантів та реемігрантів, хворих на депресивні розлади різного ґенезу, про що свідчать особливості виявленої нами в процесі дослідження психопатологічної симптоматики.

2. Пацієнти з психогенними депресивними розладами найбільше піддаються впливу фактора еміграції, порівняно з пацієнтами з ендогенними та органічними депресіями.

3. Контингент емігрантів та реемігрантів відрізняється значуще більш вираженими ознаками соматизації, обсесивно-компульсивних розладів і тривожності, дещо вищими компонентами ворожості та фобічної тривожності.

4. Найбільш вираженими показниками, що характеризують депресивні та астенічні тенденції у реемігрантів, були ознаки депресії та міжособистісної сенситивності, а також індекс виразності дистресу. На наш погляд, причинами цих відмінностей є вплив об'єктивного фактора фрустрації у групі реемігрантів та тривожних побоювань щодо можливості продовження роботи за кордоном у зв'язку із психічним захворюванням - у емігрантів.

Перспективи подальших досліджень. 3 огляду на отримані в процесі даного дослідження результати, основними перспективами подальших досліджень $є$ розробка диференційних лікувально-реабілітаційних та профілактичних заходів щодо депресивних розладів у емігрантів та реемігрантів з урахуванням виявлених особливостей.

\section{ЛІТЕРАТУРА}

1. Міграція в Україні: факти і цифри / Міжнародна організація з міграції. - Київ : Представництво МОМ в Україні. - 2011. - 7 с.

2. Incidence of psychotic disorders in immigrant groups to the Netherlands / J. P. Selten, N. Veen, W. Feller [et al.] // British Journal of Psychiatry. - 2001. - No. 178. - P. 367-372.

3. Gavin B. E. The mental health of migrants / B. E. Gavin, B. D. Kelly, A. Lane [et al.] // Irish Medical Journal. - 2001. Vol. 94. - P. 229-230.

4. Lauber C. Patterns of Psychiatric Inpatient Care in Migrants: Results from Switzerland / C. Lauber, B. Lay, W. Rossler // Swiss Medical Weekly. - 2006. - No. 135. - P. 50-56.

5. Иванова М.В.Психическое здоровье мигрантов (клинический, социально-психологический и реабилитационный аспекты): дис. на соискание ученой степени

\section{REFERENCES}

1. (2011). Mihratsiia v Ukraini: fakty i tsyfry. Mizhnarodna orhanizatsiia z mihratsii [Migration in Ukraine: Facts and figures. International Organization for Migration]. Kyiv: Predstavnytstvo MOM v Ukraini [in Ukrainian].

2. Selten, J.P. (2001). Incidence of psychotic disorders in immigrant groups to the Netherlands. British Journal of Psychiatry, 178, 367-372. канд. мед. наук: 14.01.18 / Марина Владимировна Иванова; НИИ психического здоровья СО РАМН. - Томск, 2007. 205 c.

6. Некоторые особенности психологической адаптации мигрантов [Електронний ресурс] / В. Б. Колянова, В.П. Боряк, Н. В. Барнаш, Л. В. Михайленко. - Режим доступу: http://migrocenter.ru/publ/konfer/kavkaz/m_kavkaz030. php.

7. Кириленко Я. Интердисциплинарные аспекты миграции [Електронний ресурс] / Я. Кириленко, Е. Чуманская // Архів Національної бібліотеки ім. В. Вернадського. - 2011. - Т. 15, № 2 (55). - С. 52-53. Режим доступу: http://archive.nbuv.gov.ua/portal/chem_biol/Tzhp/ 2011_2/pdf/52-53.pdf.

3. Gavin, B.E. (2001). The mental health of migrants. Irish Medical Journal, 94, 229-230.

4. Lauber, C., Lay, B., \& Rossler, W. (2006). Patterns of psychiatric inpatient care in migrants: Results from Switzerland. Swiss Medical Weekly, 135, 50-56.

5. Ivanova, M.V. (2007). Psikhicheskoye zdorovye migrantov (klinicheskiy, sotsialno-psikhologicheskiy i reabilita- 
Огляди літератури, оригінальні дослідження, погляд на проблему, ювілеї

tsionnyy aspekty) [Mental health of migrants (clinical, socialpsychological, rehabilitation aspects]. Candidate's thesis. Tomsk [in Russian].

6. Kolyanov, V.B., Borak, V.P., Barnash, N.V., \& Myhaylenko, L.V. (2009). Nekotoryye osobennosti psikhologicheskoy adaptatsii migrantov [Certain particularities of psychological adaptation of migrants]. Retrieved from: http://mig- rocenter.ru/publ/konfer/kavkaz/m_kavkaz030.php.

7. Kirilenko, Ya., \& Chumanska, E. (2011). Interdistsiplinarnye aspekty migratsii [Interdisciplinary aspects of migration]. Arkhiv Natsionalnoi biblioteky im. V. Vernadskoho - V. Vernadskyi Archive National Library, 2 (55), 52-53. Retrieved from: http://archive.nbuv.gov.ua/portal/chem_ biol/Tzhp/2011_2/pdf/52-53.pdf [in Russian].

\title{
ПСИХОПАТОЛОГИЧЕСКАЯ ФЕНОМЕНОЛОГИЯ ДЕПРЕССИВНЫХ РАССТРОЙСТВ С УЧЕТОМ ФАКТОРА МИГРАЦИИ
}

\author{
๑Е. П. Венгер, Е. Е. Смашна, Ю. И. Мисула, В. С. Билоус, Л. М. Сас,
} О. А. Люта, Я. М. Несторович, Т. П. Гусева

гвУз «Тернопольский государственный медицинский университет имени И. Я. Горбачевского МОЗ Украчны»

РЕЗЮМЕ. Современная политическая и экономическая ситуация в Украине обусловливает то, что явления эмиграции и реэмиграции входят в число самых актуальных государственных и общественных проблемных вопросов. Согласно данным Международной организации по миграции, к 2011 году количество украинских эмигрантов составляло около 6,5 млн человек (14,4 \% постоянного населения).

Цель исследования - изучение синдромологических особенностей депрессивных расстройств у эмигрантов и реэмигрантов.

Материал и методы. Клинически обследовано 98 эмигрантов, 95 реэмигрантов и 98 не эмигрантов, больных депрессивными расстройствами психогенного, эндогенного и органического характера.

Результаты. Обнаружена большая пораженность реэмигрантов типичными аффективными синдромами витальной и апатичной депрессии, а эмигрантов - атипичными аффективными синдромами, в частности, тревожно-депрессивными и ажитации, что можно объяснить влиянием объективных социально-психологических факторов, а также интрапсихической трансформацией актуальных стрессогенных раздражителей, связанных с эмиграцией и реэмиграцией.

Выводы. 1. Фактор эмиграции и реэмиграции влияет на психоэмоциональную сферу эмигрантов и реэмигрантов, больных депрессивными расстройствами различного генеза, о чем свидетельствуют особенности обнаруженной нами в процессе исследования психопатологической симптоматики. 2. Пациенты с психогенными депрессивными расстройствами наиболее подвержены воздействию фактора эмиграции, по сравнению с пациентами с эндогенными и органическими депрессиями. 3. Контингент эмигрантов и реэмигрантов отличается значимо более выраженными признаками соматизации, обсессивно-компульсивных расстройств и тревожности, более высокими компонентами враждебности и фобической тревожности. 4. Наиболее выраженными показателями, характеризующими депрессивные и астенические тенденции у реэмигрантов, были признаки депрессии и межличностной сенситивности, а также индекс выраженности дистресса. На наш взгляд, причинами этих различий является влияние объективного фактора фрустрации в группе реэмигрантов и тревожных опасений относительно возможности продолжения работы за рубежом в связи с психическим заболеванием - у эмигрантов.

КЛЮЧЕВЫЕ СЛОВА: миграция; депрессивное расстройство; психогенные депрессивные расстройства; эндогенные депрессивные расстройства; органические депрессивные расстройства.

\section{PSYCHOPATHOLOGICAL PHENOMENOLOGY OF DEPRESSIVE DISORDERS IN EMIGRANTS AND RE-EMIGRANTS}

\author{
๑O. P. Venher, O. E. Smashna, Yu. I. Mysula, V. S. Bilous, L. M. Sas, \\ O. O. Liuta, Ya. M. Nestorovych, T. P. Huseva \\ I. Horbachevsky Ternopil State Medical University
}

SUMMARY. The current political and economic situation in Ukraine is due to the fact that the phenomena of emigration and re-immigration are one of the most urgent issues of state and social issues. According to the International Organization for Migration, as of 2011, the number of Ukrainian emigrants was about 6.5 million people ( $14.4 \%$ of the permanent population).

The aim of the study - to learn the syndromological features of depressive disorders in emigrants and re-emigrants.

Material and Methods. 98 emigrants, 95 re-emigrants and 98 non-emigrants, patients with depressive, psychogenic, endogenous and organic disorders were clinically examined. 


\section{Огляди літератури, оригінальні дослідження, погляд на проблему, ювілеї}

Results. Re-emigrants were more affected by typical affective syndromes - aphastic and depressive, and emigrants with atypical affective syndromes, in particular, anxiety-depressive and agitation, which can be explained by the influence of objective socio-psychological factors, as well as intrapsychic transformation of topical stress-inducing stimuli, with emigration and re-emigration.

Conclusions. 1. The factor of emigration and re-emigration affects the psycho-emotional sphere of emigrants and re-emigrants suffering from depressive disorders of various genesis, as evidenced by the features revealed by us in the process of psychopathological symptomatology research. 2. Patients with psychogenic depressive disorders are most susceptible to the effects of emigration compared to patients with endogenous and organic depressions. 3. The contingent of emigrants and re-emigrants has significantly more pronounced signs of somatization, obsessive compulsive disorder and anxiety, somewhat higher components of hostility and phobic anxiety. 4. The most pronounced indicators that characterize the depressive and asthenic tendencies of the re-emigrants were the signs of depression and interpersonal sensitivity, as well as the index of severity of distress. In our opinion, the causes of these differences are the influence of the objective frustration factor in the group of re-immigrants and anxiety concerns about the possibility of continuing work abroad in connection with mental illness - in emigrants.

KEY WORDS: migration; depressive disorder; stress-related depressive disorder; endogenic depressive disorder; organic-caused depressive disorder. 